\title{
Porous alkali activated materials with slow alkali release dynamic. Role of composition
}

\author{
G. Bumanis and D. Bajare \\ Institute of Materials and Structures, Riga Technical University, (Riga, Latvia) \\ $\bowtie$ girts.bumanis@rtu.lv
}

Received 30 December 2016

Accepted 5 May 2017

Available on line 7 February 2018

\begin{abstract}
Alkali activated materials (AAM) based on calcined metakaolin or illite clay together with waste by-products, such as waste glass or aluminium scrap recycling waste, were tested as value-added materials for $\mathrm{pH}$ stabilization in biogas technology where decrease of $\mathrm{pH}$ should be avoided. Porous materials with ability to slowly leach alkalis in the water media thus providing continuous control of the $\mathrm{pH}$ level were obtained. XRD, FTIR, SEM and titration methods were used to characterize AAM and their leaching properties. It is clear that composition of the material has an important effect on the diffusion of alkali from structure. Namely, higher $\mathrm{Si} / \mathrm{Al}$ and $\mathrm{Na} / \mathrm{Al}$ molar ratios may increase pore solution transfer to the leachate. The leaching rate of alkalis from the structure of AAM is high for the first few days, decreasing over time. It was possible to calculate the buffer capacity from the mixture design of AAM.
\end{abstract}

KEYWORDS: Alkali-activated cement; Waste treatment; Diffusion; Microstructure, $\mathrm{pH}$

Citation/Citar como: Bumanis, G.; Bajare, D. (2018) Porous alkali activated materials with slow alkali release dynamic. Role of composition. Mater. Construcc. 68 [329], e145 https://doi.org/10.3989/mc.2018.14016

RESUMEN: Materiales activados alcalinamente porosos con liberación lenta de álcalis. Efecto de la composición. En este estudio se han ensayado materiales activados alcalinamente (AAM) basados en metacaolín o arcilla de ilita junto con subproductos tales como residuos de vidrio o aluminio reciclado, como materiales con valor añadido para la estabilización del $\mathrm{pH}$ en tecnologías de biogás donde se debe evitar la disminución del pH . Se obtuvieron materiales porosos con capacidad para lixiviar lentamente los álcalis en medios acuosos, proporcionando así un control continuo del nivel de $\mathrm{pH}$. Se utilizaron técnicas de DRX, FTIR, SEM y métodos de tritación para caracterizar los AAMs y sus propiedades de lixiviación. La composición del material tiene un efecto importante en la difusión del álcali de la estructura. Es decir, mayores relaciones molares de $\mathrm{Si} / \mathrm{Al}$ y $\mathrm{Na} / \mathrm{Al}$ pueden aumentar la transferencia de la solución del poro al lixiviado. La tasa de lixiviación de los álcalis desde la estructura de los AAMs es alta durante los primeros días, disminuyendo con el tiempo. Se ha calculado la capacidad del efecto tampón a partir del diseño de mezcla de AAM.

Palabras clave: Cemento activado alcalinamente; Tratamiento de residuos; Difusión; Microestructura, $\mathrm{pH}$

ORCID ID: G. Bumanis (http://orcid.org/0000-0002-6617-0120); D. Bajare (http://orcid.org/ 0000-0002-3250-5594)

Copyright: (C) 2018 CSIC. This is an open-access article distributed under the terms of the Creative Commons Attribution 4.0 International (CC BY 4.0) License.

\section{INTRODUCTION}

Biogas technology provides an alternative source of energy to fossil fuels in many parts of the world. Using local resources, such as agricultural crop residues, municipal solid or food wastes, market wastes and animal waste, energy (biogas) and manure are derived by anaerobic digestion. Traditionally zeolites are used for the immobilization of microorganisms in anaerobic reactors to 
stabilize and optimize the process efficiency (1). In this study porous alkali activated materials (AAM) produced from calcined clay and industrial wastes using alkali activation technology were used for optimization of biogas production technology instead of well-known zeolites.

It is known that low-calcium AAMs (geopolymers) are amorphous to semi-crystalline materials that are formed by transformation of alumino-silicates at low temperature in a very short time. The fundamental structures in low-calcium alkali activated systems based on metakaolin are highly disordered, highly cross-linked alumosilicate gel. The alkali solutions (activators) of AAM are typically a mixture of $\mathrm{NaOH}, \mathrm{KOH}, \mathrm{Na}_{2} \mathrm{SiO}_{3}$ and $\mathrm{K}_{2} \mathrm{SiO}_{3}$. It is apparent that the pore solution of AAM contains high concentration of alkali metal cations, typically more than $500 \mathrm{mM}$ in several cases even exceeding $1 \mathrm{M}(2)$, and leaching rate for $\mathrm{Na}^{+}$is high, reaching tens of $\mathrm{g} / \mathrm{m}^{2} /$ day (tens of $\mu \mathrm{m} /$ day) for the first few weeks and decreasing over time (3). Xie and Ozbakkaloglu observed the leaching of dense low-calcium fly and bottom ash-based geopolymers and described it as efflorescence and the diffusion of alkali salts from the structure of the material (4). The presence of calcium in the composition of the binder has an important effect on the diffusion of alkalis from AAM. Binders containing significantly lower levels of calcium appear to have approximately 10 times higher effective diffusion coefficients than their high-Ca counterparts. This is highly significant key finding for creation of material with high alkali diffusion for restricting $\mathrm{pH}$ decrease in a biogas reactor where acid substances are used. It was seen in previous research that calcium in an AAM is important in the formation of a low-permeability pore system; alkali diffusion measurements confirm these observations and highlight the role of $\mathrm{Ca}$ in reducing effective alkali diffusion coefficients by up to an order of magnitude (2). The general increase in aluminium content of the AAMs followed by decreasing calcium content was examined by $\mathrm{P}$. Duxson. It was expected that tetrahedral aluminium would remove alkali cations from the pore solution and incorporate them into the gel, as has been previously observed for metakaolin-derived alkali aluminosilicate (geopolymer) gels (5). It is possible to draw parallels with calcium aluminosilicate hydrate $(\mathrm{C}-\mathrm{A}-\mathrm{S}-\mathrm{H})$ gels in ordinary Portland cement systems, where decrease of the aluminium content in the binder increases the amount of alkalis remaining in the pore solution (6).

The amount of initially dissolved silica present in the activating solution significantly affects the amount of alkali remaining in the pore solution. An inverse correlation observed between silica and alkalis indicated that higher silicate content leads to a higher degree of reaction and thus less residual alkalis in high-alkali systems (2). In a similar manner higher $\mathrm{SiO}_{2}$ content (Si/Al 2.26 to 3.76) increases compressive strength of AAM matrix from 38 to $51 \mathrm{MPa}$ (7). This correlates well with the theory developed in the previous research work of Lloyd in which dissolved silica in the activating solution enhances formation of the binder by preventing re-precipitation of dissolved species on to the surface of ash particles (8). Previous studies have confirmed (Lloyd et al) that extraction of pore solutions from hardened AAMs is rich with alkali ions and can reach $\mathrm{pH} 13$, with a relatively low dissolved $\mathrm{Si}$ concentration. However, these materials consist some soluble $\mathrm{Ca}$ playing a buffering role similar to $\mathrm{Ca}(\mathrm{OH})_{2}$ (2). Therefore the specific pore structure of AAM together with the capacity to release alkali into water media during prolonged time period indicate possible new fields for their application. Porous AAMs with density from 400 to $800 \mathrm{~kg} / \mathrm{m}^{3}$ using an aluminum powder as blowing agent have been described by Hlaváček et al. but this study did not include diffusion and leaching properties (9).

Important finding in alkali activation technology is the fact that the hazardous waste could be used as raw material due to AAM capability to immobilize hazardous heavy metals $(10,11)$. One of the hazardous materials used in this research is aluminium scrap recycling waste (ASRW). In aluminium scrap recycling industry salt slag, a mixture of salts, aluminium oxide, aluminium metal and impurities are typical residue generated during re-melting of aluminium scrap/dross under a salt layer in rotary furnaces. As it has been classified as toxic and hazardous waste (highly flammable, irritant, harmful and leachable), landfill disposal of this residue is forbidden in most of the European countries and it should be recycled (12). In this study ASRW was used in the composition of AAM as secondary raw material. Due to the specific chemical composition of ASRW and its reactivity at alkaline media, porous structures of AAMs were obtained. Bai et al. has reported that high strength geopolymer foams with total porosity $81 \%$ and open porosity $79 \%$ could be obtained using hydrogen peroxide (13). Two types of thermally treated clays were chosen as precursor of AAM: metakaolin (MK) or calcined illite clay (IC). Recycled glass (LSG) was used to modify composition of AAM. The aim of this study was to create porous AAM with predetermined buffering capacity and with ability to slowly leach alkalis in the water media in a long term in order to restrict $\mathrm{pH}$ decrease in biogas production process where acidic substances are used and created.

\section{MATERIALS AND METHODS}

The novel materials obtained in this research were low-calcium alkali-activated materials (AAM) based on calcined kaolin clay (Surin-Kaolin Ltd., Poland) or calcined local illite clay (Lode Ltd., 
Latvia). The additional secondary raw materials used in this research were aluminium scrap recycling waste (ASRW) received from aluminium scrap recycling industry facility (Dilers Ltd., Latvia) and glass waste (LSG) received from the glass recycling factory (Lampu Demerkurizacijas Centrs Ltd., Latvia). In order to increase homogeneity and fineness of the novel material, raw materials were ground for 30 minutes using planetary ball mill Retsch PM 400.

The particle size distribution of powdered raw materials was determined by laser granulometer Analysette 22 Nano Tec. BET method (QuadraSorb) was used to determine the surface area of the powdered raw materials. The elemental analysis of ASRW was carried out at Forschungsinstitut fur Nichteisenmetalle Freiberg GmbH (Germany) including inductively coupled plasma optical emission spectrometry (ICP-OES) for $\mathrm{Al}$ and $\mathrm{Si}$, atomic absorption spectrometry (AAS) for $\mathrm{Na}, \mathrm{Mg}, \mathrm{K}, \mathrm{Ca}$, $\mathrm{Fe}, \mathrm{Cu}, \mathrm{Zn}, \mathrm{Pb}$, and potentiometer titration analyses (PTA) to determine $\mathrm{Cl}$ as well as combustion process to determine $\mathrm{S}$.

The total porosity was determined according to ASTM C188 and the open porosity was measured according to LVS EN 1097-6. Scanning electron microscope (SEM) (Tescan Mira/LMU) was used for microstructural investigation of AAM. Mineralogical composition of raw materials and AAM was determined by X-ray diffraction (XRD) (PAN analytical X'Pert PRO) Chemical composition of raw materials was determined according to LVS EN 196-2 with sensibility $\pm 0.5 \mathrm{w} \%$. Structural characterization of raw materials and AAM involving different functional groups was performed with Fourier transform infrared (FTIR) spectrometer (VARIAN 800 FT-IR) between 400 and $4000 \mathrm{~cm}^{-1}$.

AAM were characterized by XRD, FTIR and SEM after 28 day curing at room environment $\left(20 \pm 2^{\circ} \mathrm{C}\right.$, RH $\left.60 \pm 5 \%\right)$. Diffusion of hydroxide ions was tested for 28 days old AAM by immersing cubical specimens (weight $3.5 \pm 0.5 \mathrm{~g}$ ) in the deionized water and by measuring the eluted $\mathrm{OH}^{-}$ion concentration over time. Samples were moved to a new bath with deionized water $(50 \mathrm{ml})$ with interval $24 \mathrm{~h}$ during 20 days. Titration method to $\mathrm{pH} 7.0$ with $0.01 \mathrm{M} \mathrm{HCl}$ was applied every day to determine the released amount of $\mathrm{OH}^{-}$ions in deionized water from all samples. $\mathrm{pH}$ level of the water solution was determined with portable $\mathrm{pH} / \mathrm{mV}$ meter with sensor check HI 991003 and amount of $\mathrm{OH}^{-}$ions as mol/l/g AAM was calculated.

\subsection{Calcined clays}

The process of calcination of raw clay in an air atmosphere rotary furnace at $800{ }^{\circ} \mathrm{C}$ for $30 \mathrm{~min}$ was used obtain metakaolin (MK) and calcined illite clay (IC) in the laboratory setting. The specific surface area of ground MK was $15.86 \mathrm{~m}^{2} / \mathrm{g}$ and of IC $-21.42 \mathrm{~m}^{2} / \mathrm{g}$. The average diameter of MK particles was $743.1 \mathrm{~nm}$ and of IC $-709.5 \mathrm{~nm}$. According to XRD analysis, MK used is largely amorphous, with minor crystalline phases such as quartz $\left(\mathrm{SiO}_{2}\right)$, mica $\mathrm{KAl}_{3} \mathrm{Si}_{3} \mathrm{O}_{11}$ and muscovite $\left(\mathrm{K}_{0.82} \mathrm{Na}_{0.18}\right)\left(\mathrm{Fe}_{0.03} \mathrm{Al}_{1.97}\right)$ (Figure 1a). Calcined IC had more crystalline structure and, in addition to quartz $\left(\mathrm{SiO}_{2}\right)$ and illite $\mathrm{K}(\mathrm{AlFe})_{2} \mathrm{AlSiO}_{3} \mathrm{O}_{10}(\mathrm{OH})_{2} \cdot \mathrm{H}_{2} \mathrm{O}$, it also contained microcline $\left(\mathrm{KAlSiO}_{8}\right)$ (Figure 1b). Chemical composition of both calcined clays is given in Table 1 .

The results of FTIR spectroscopy of calcined clays show the characteristic bands of MK and IC (Figure 2a, b). The mode at $913 \mathrm{~cm}^{-1}$ corresponds to $\mathrm{Al}-\mathrm{OH}$ band and $\mathrm{Si}-\mathrm{O}-\mathrm{Al}^{\mathrm{VI}}$ band is characterized with frequency at $540 \mathrm{~cm}^{-1}$ (Figure 2a) $(14,15)$. Band at $800 \mathrm{~cm}^{-1}$ could be related to the change from octahedral coordination of $\mathrm{Al}^{3+}$ in kaolinite to tetrahedral coordination in metakaolin $(14,15)$. Wavenumbers at 1031, 1008 and $469 \mathrm{~cm}^{-1}$ (Figure 2a, b) correspond to $\mathrm{Si}-\mathrm{O}$ band, and also quartz interference could occur at $1085 \mathrm{~cm}^{-1}$ (Figure 2a).
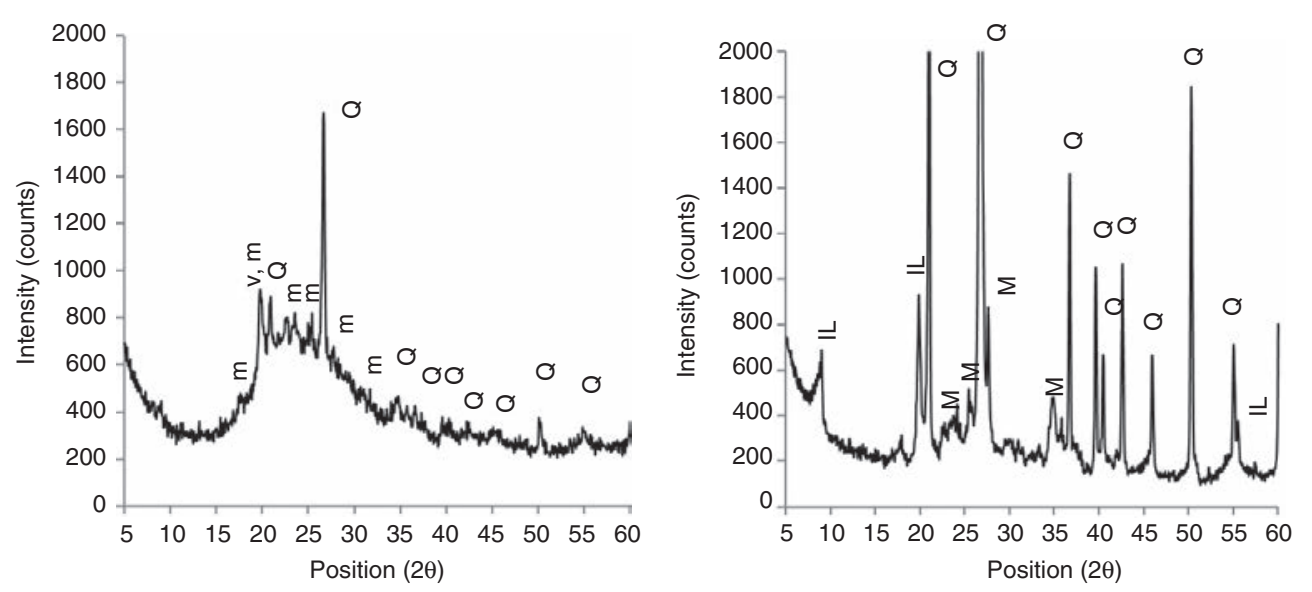

FIGURE 1. XRD pattern of clays calcined at temperature $800^{\circ} \mathrm{C}$. (a) metakaolin; (b) illite clay. $\mathrm{Q}=$ quartz (46-1045), $\mathrm{m}=$ muscovite (80-0743), $v=$ mica (46-0741), IL - illite (02-0050), M - microcline (19-0926). 

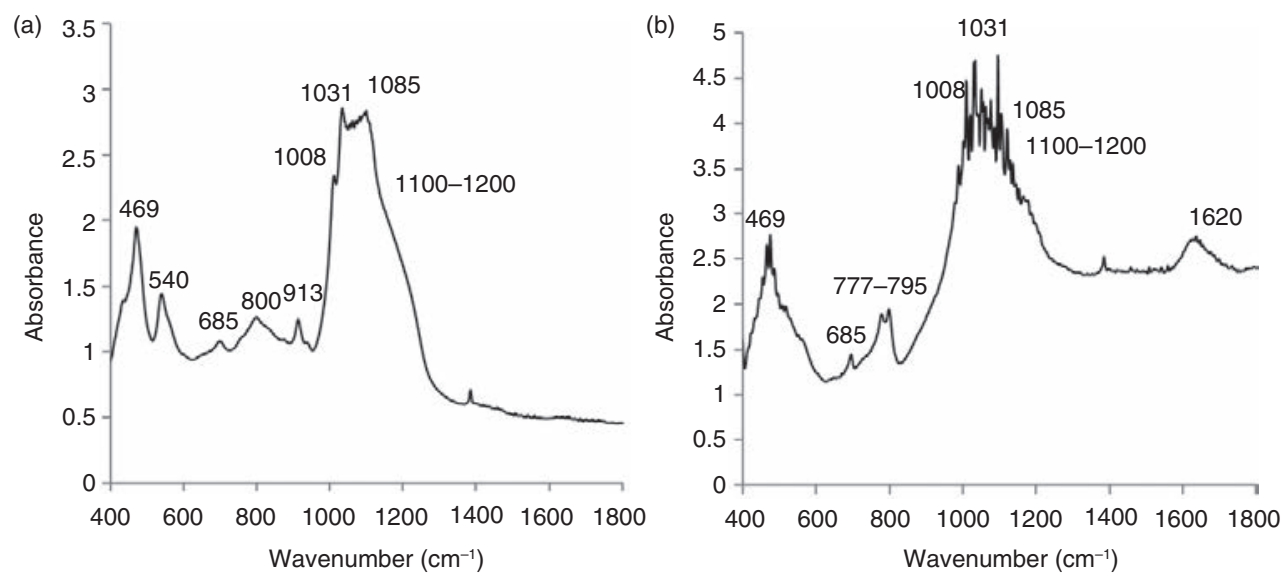

FIGURE 2. FTIR pattern of clays calcined at temperature $800^{\circ} \mathrm{C}$. (a) metakaolin; (b) illite clay.

The shoulder at 1100 and $1200 \mathrm{~cm}^{-1}$ (Figure 2a, b) is attributed to amorphous $\mathrm{SiO}_{2}(14)$. Band at $685 \mathrm{~cm}^{-1}$ could be attributed to the spinel phase $\left(\mathrm{MgAl}_{2} \mathrm{O}_{4}\right)$ which occurs during the calcination of the selected clays (16). Calcined IC has infrared vibration modes at $1620 \mathrm{~cm}^{-1}$ (Figure $2 \mathrm{~b}$ ) associated with bending vibrations of $\mathrm{H}-\mathrm{O}$ bond. The doublet at $777-795$ $\mathrm{cm}^{-1}$ is characteristic of the quartz $(17,18)$, which was not detected for MK.

\subsection{Aluminium scrap recycling waste (ASRW)}

The ASRW is final waste product at the aluminium scrap recycling factories. Chemical composition of ASRW is given in Table 1. The elemental analysis by ICP-OES, AAS and PTA of the ASRW showed the following content: aluminium $-34.4 \%$, silicon $4.4 \%$, magnesium $-2.44 \%$, calcium $-1.3 \%$, sodium $1.7 \%$, potassium $-2.3 \%$, sulphur $-0.1 \%$, chlorine $-4.2 \%$, iron $-3.6 \%$, copper $-1.0 \%$, lead $-0.1 \%$, and zinc $-0.6 \%$. According to the XRD data, the ASRW contained metallic aluminium (Al), iron sulphite $\left(\mathrm{FeSO}_{3}\right)$, aluminium nitride (AlN), corundum $\left(\mathrm{Al}_{2} \mathrm{O}_{3}\right)$, aluminium iron oxide $\left(\mathrm{Fe} \mathrm{AlO}_{3}\right)$, magnesium dialuminium $\left(\mathrm{MgAl}_{2} \mathrm{O}_{4}\right)$, quartz $\left(\mathrm{SiO}_{2}\right)$, aluminium chloride $\left(\mathrm{AlCl}_{3}\right)$ and aluminium hydroxide $\left(\mathrm{Al}(\mathrm{OH})_{3}\right)$ (Figure 3).

\subsection{Glass waste from fluorescent lamp recycling factory (LSG)}

The LSG was obtained from fluorescent lamp recycling process, which includes lamp classification, glass separation, cleaning from harmful components and glass grinding. The chemical composition of LSG is given in Table 1 . The results of grading analysis showed that the additionally ground material contains a wide range of particle sizes: from $8 \mu \mathrm{m}$ to $30 \mu \mathrm{m}$ with the average grain size of $26.3 \mu \mathrm{m}$. The specific surface area of LSG was $1.126 \mathrm{~m}^{2} / \mathrm{g}$.
TABLE 1. Chemical composition of raw materials (wt. \%)

\begin{tabular}{lcccc}
\hline Chemical component & ASRW & IC & MK & LSG \\
\hline $\mathrm{Al}_{2} \mathrm{O}_{3}$ & 63.19 & 14.60 & 25.55 & 1.03 \\
$\mathrm{SiO}_{2}$ & 7.92 & 73.84 & 63.65 & 68.07 \\
$\mathrm{CaO}$ & 2.57 & 0.91 & 3.47 & 1.39 \\
$\mathrm{SO}_{3}$ & 0.36 & - & - & - \\
$\mathrm{TiO}_{2}$ & 0.53 & 0.63 & - & - \\
$\mathrm{MgO}$ & 4.43 & 1.10 & 1.97 & - \\
$\mathrm{Fe}_{2} \mathrm{O}_{3}$ & 4.54 & 4.08 & 0.51 & 0.19 \\
$\mathrm{PbO}$ & - & - & - & 20.02 \\
$\mathrm{Na}_{2} \mathrm{O}$ & 3.84 & 0.06 & 3.75 & 8.02 \\
$\mathrm{~K}_{2} \mathrm{O}$ & 3.81 & 2.75 & 0.45 & 1.17 \\
$\mathrm{Other}$ & 2.60 & 1.05 & 0.53 & 0.11 \\
LOI, $1000{ }^{\circ} \mathrm{C}$ & 6.21 & 0.98 & 0.21 & - \\
\hline
\end{tabular}

\subsection{Alkali activation solution}

The AAM were prepared by using alkali activating solution with silica modulus $\mathrm{M}_{\mathrm{s}} 1.67\left(\mathrm{SiO}_{2}\right.$ to $\mathrm{Na}_{2} \mathrm{O}$ ratio) defined with previous research performed on alkali activation solution properties on AAM structure (19). Alkali activators were prepared by using commercially available sodium silicate solution from "Vincents Polyline" Ltd. characterized by the silica modulus $\mathrm{M}_{\mathrm{s}}=3.22$. To obtain alkali activation solution with the required chemical composition, the modification with an addition of sodium hydroxide was done. Commercially available sodium hydroxide flakes from "Tianye Chemicals" (China) with 99\% purity were used.

\section{EXPERIMENTAL SETUP}

It was possible to obtain a porous structure of AAM due to the specific chemical composition of ASRW and its reactivity in alkaline media. LSG was used to modify alkalization process of clays by 


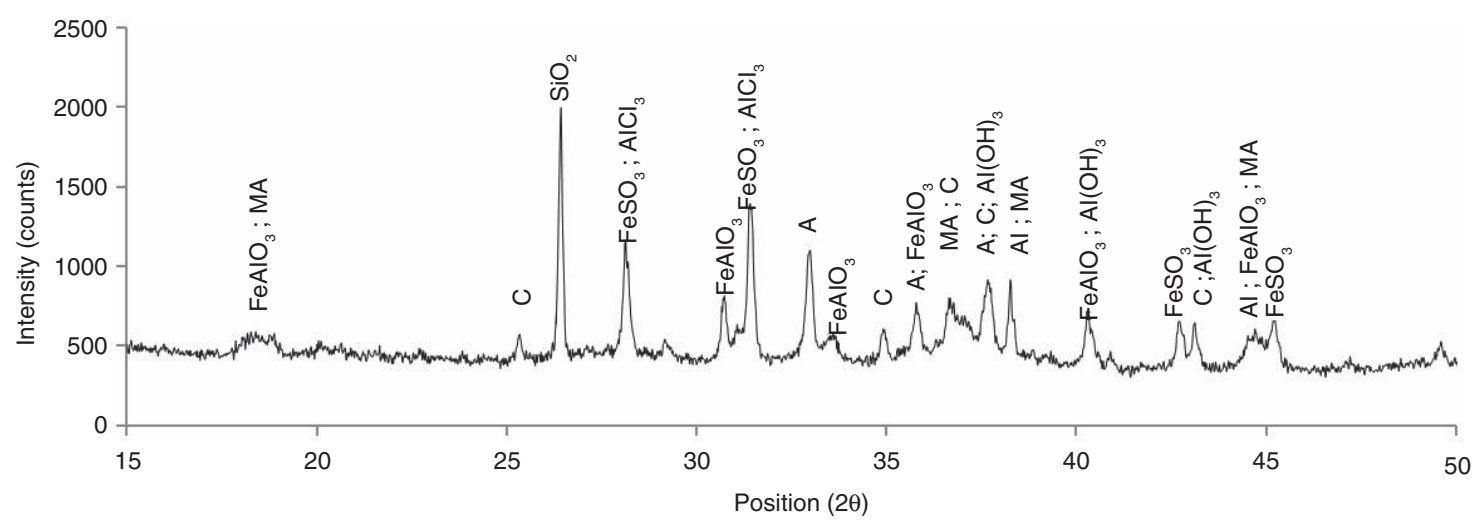

FigURE 3. XRD pattern of aluminium scrap recycling waste. $\mathrm{A}=$ Aluminum Nitride $\mathrm{AlN}(08-0262), \mathrm{C}=$ corundum $\mathrm{Al}_{2} \mathrm{O}_{3}$, (71-3646), $\mathrm{MA}=$ magnesium dialuminium oxide $\mathrm{MgAl}_{2} \mathrm{O}_{4}$ (82-2424).

increasing $\mathrm{SiO}_{2}$ content in the mixture (20). Dry raw materials were mixed with the activation solution with silica modulus $\mathrm{M}_{\mathrm{s}} 1.67$ at a constant solution/ dry mixture ratio of 0.70 (Table 2). After mixing, $100 \mathrm{~g}$ of this paste were immediately poured into prismatic moulds measuring $4 \times 4 \times 16 \mathrm{~cm}$. Moulds were covered with plastic film and then stored at 80 ${ }^{\circ} \mathrm{C}$ for $24 \mathrm{~h}$. After demoulding specimens were kept at room environment $\left(20 \pm 2{ }^{\circ} \mathrm{C}, \mathrm{RH} 60 \pm 5 \%\right)$ until the planned tests were performed.

\section{RESULTS AND DISCUSSION}

\subsection{XRD}

The structures of MK-A1-G1 and MK-A1-G0 were „X-ray amorphous”. Both of XRD patterns had a halo in the $2 \theta=15-40^{\circ}$ region, which is characteristic for amorphous and/or vitreous compounds (Figure 4). The broad peak observed from 20 to $30^{\circ} 2 \theta$ in MK (Figure 1a) has become wider to $40^{\circ} 2 \theta$ after the reaction with activator $M_{\mathrm{s}} 1.67$ and shifted to higher angle (Figure 4a), as is known to occur during geopolymer formation from MK. This shift demonstrates the formation of new amorphous phases, usually described as geopolymeric gels $(21,22)$. The presence of the halo can be explained by formation of alkali aluminosilicate gel as the primary reaction product in activation of MK as well as presence of LSG in the composition of MK-A1-G1, where the halo is more pronounced. Generally speaking, the only crystalline phase, which could be identified clearly by XRD analysis, was quartz. Significant difference in the mineralogical composition between AAM made with or without LSG was not determined. The structure of AAM made with IC was not completely X-ray amorphous comparing with AAM made of MK (Figure 4). The halo for IC-A1-G0 and IC-A1-G1 was not strongly marked in the diffractograms in comparison with MK which can be explained by
TABLE 2. Mixture composition and physical properties of alkali activated materials (AAM)

\begin{tabular}{lcccc}
\hline & \multicolumn{4}{c}{ Component (weight parts) } \\
\cline { 2 - 5 } Composition & MK & IC & ASRW & LSG \\
\hline IC-A1-G0 & - & 1 & 1 & 0 \\
IC-A0.5-G0 & - & 1 & 0.5 & 0 \\
IC-A0.1-G0 & - & 1 & 0.1 & 0 \\
IC-A1-G1 & - & 1 & 1 & 1 \\
IC-A0.5-G1 & - & 1 & 0.5 & 1 \\
IC-A0.1-G1 & - & 1 & 0.1 & 1 \\
MK-A1-G0 & 1 & - & 1 & 0 \\
MK-A0.5-G0 & 1 & - & 0.5 & 0 \\
MK-A0.1-G0 & 1 & - & 0.1 & 0 \\
MK-A1-G1 & 1 & - & 1 & 1 \\
MK-A0.5-G1 & 1 & - & 0.5 & 1 \\
MK-A0.1-G1 & 1 & - & 0.1 & 1 \\
\hline & & & &
\end{tabular}

the crystalline mineralogical composition of IC calcined at temperature $800^{\circ} \mathrm{C}$.

\subsection{FTIR}

The infrared spectra (FTIR) for all the samples studied are given in Figure 5. All AAM specimens with and without glass waste have mode at $446 \mathrm{~cm}^{-1}$ which corresponds to $\mathrm{Si}-\mathrm{O}-\mathrm{Si}$ or Al-O$\mathrm{Si}$ bands $(22,23)$. Mode at $540 \mathrm{~cm}^{-1}$ is typical only for MK-A1-G0 and IC-A1-G0 and it is associated with $\mathrm{Si}-\mathrm{O}-\mathrm{Al}$ bands, where $\mathrm{Al}$ is present in octahedral coordination. In the FTIR spectrums doublet at $777-795 \mathrm{~cm}^{-1}$ (Figure 5b) is attributed to $\mathrm{Si}-\mathrm{O}-\mathrm{Si}$ bands recognized as quartz (17). The small modes at $688 \mathrm{~cm}^{-1}$ could be attributed to the symmetrical stretching vibration of $\mathrm{Si}-\mathrm{O}-$ Si or Al-O-Si bonds (Figure 5a) (23). The bending vibration of the same bonds was identified at $457 \mathrm{~cm}^{-1}$ (Figure $5 \mathrm{~b}$ ) (18). 

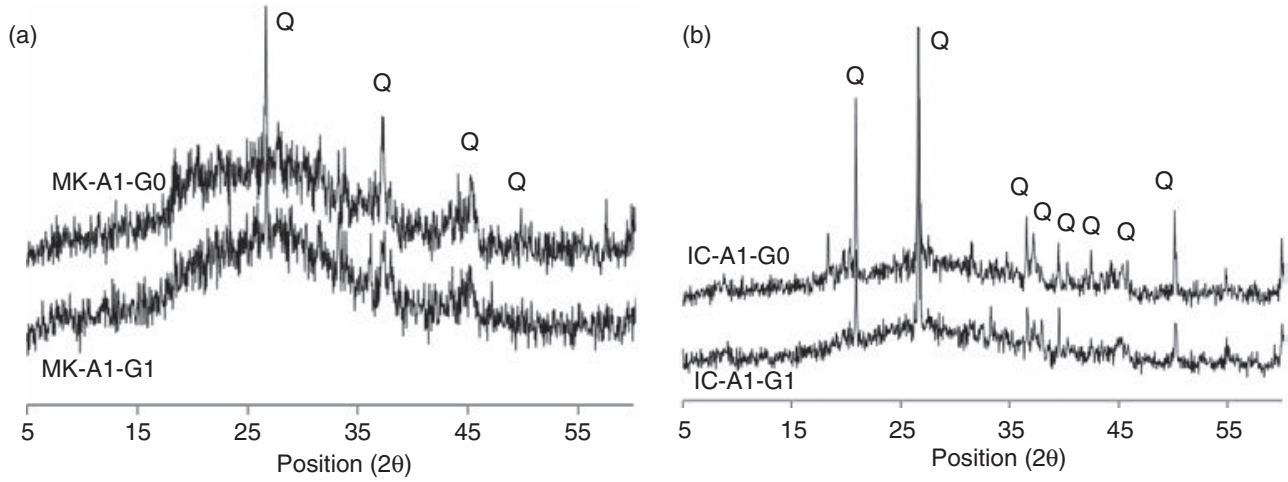

FIGURE 4. XRD patterns of AAM: (a) MK-A1-G0 (upper) without glass waste and MK-A1-G1 (lower) with glass waste cured at room environment; (b) IC-A1-G0 (upper) without glass waste and IC-A1-G1 (lower) with glass waste cured at room environment. $\mathrm{Q}=$ quartz (79-1910)
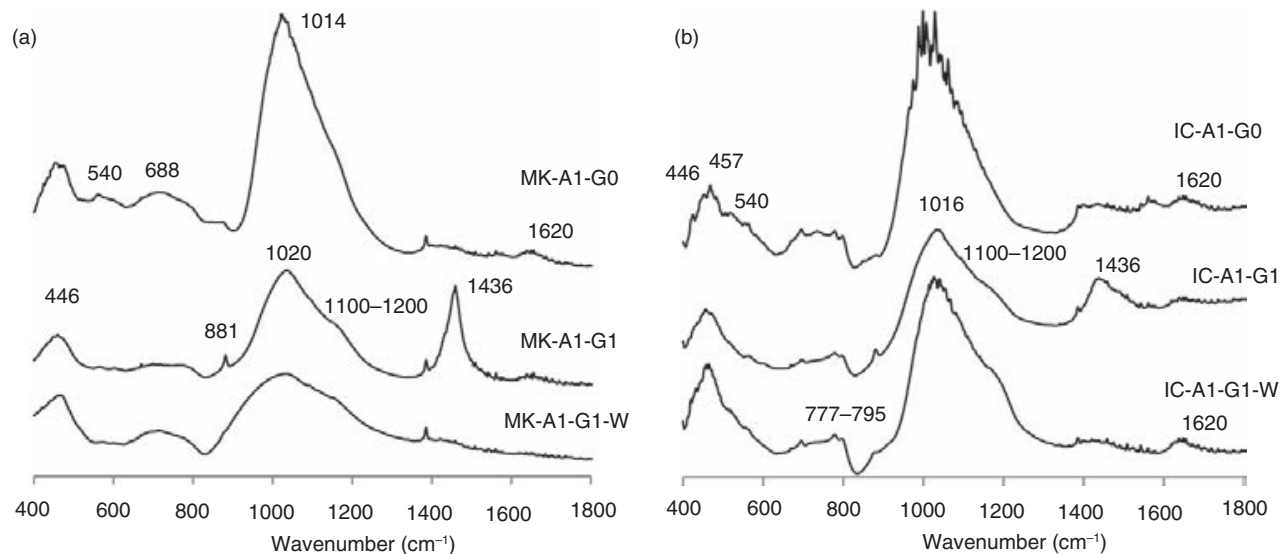

FIGURE 5. FTIR patterns of AAM: (a) MK-A1-G0 without LSG in the composition (upper), MK-A1-G1 with LSG in the composition (middle) and MK-A1-G1-W with LSG in the composition after immersion in water for 20 days (lower) and (b) IC-A1-G0 without LSG in the composition (upper), IC-A1-G1 with LSG in the composition (middle) and IC-A1-G1-W with LSG in the composition after immersion in water for 20 days (lower).

The vibrational band for calcined MK and IC with a maximum at $1085 \mathrm{~cm}^{-1}$ (Figure 2) shifted toward lower frequencies for AAM made with MK and IC, whereas that at $800 \mathrm{~cm}^{-1}$ it disappeared after the alkaline activation. Both modes indicate that the original aluminosilicate structure of the MK and IC was significantly depolymerized and dissolved by the alkaline solutions. For MK-A1-G1 the maximum of the vibrational band appeared at $1020 \mathrm{~cm}^{-1}$ (Figure 5a), whereas for IC-A1-G1 the maximum located at 1016 $\mathrm{cm}^{-1}$ (Figure $5 \mathrm{~b}$ ). These bands have broad shape due to the overlapping of various types of bonds, which include $\mathrm{Si}-\mathrm{O}$, $\mathrm{Si}-\mathrm{O}-\mathrm{Si}, \mathrm{Si}-\mathrm{O}-\mathrm{Al}$, and probably $\mathrm{Si}-\mathrm{O}-$ $\mathrm{Al}-(\mathrm{Na})$, resulting from the fine intermixing of phases (24). The shoulder at $1100-1200 \mathrm{~cm}^{-1}$ is assigned to amorphous $\mathrm{SiO}_{2}$ which indicates that polymerization was not fully completed or amorphous $\mathrm{SiO}_{2}$ remained unreacted for AAM made with glass (MK-A1-G1 and IC-A1-G1). It seems that presence of the LSG prevents complete reaction of raw materials in alkali media and formation of $\mathrm{Al}-\mathrm{O}$ and $\mathrm{Si}-\mathrm{O}$ bands. A lower degree of polymerization of silicates within the remaining gel was observed for samples with LSG. It can be explained by vitreous structure of specimens containing LSG which limits reaction between activator and calcined clay minerals. Therefore the $\mathrm{NaOH}$ is available for crystallization on the pore surface and it turns to carbonates in the open air atmosphere.

The most important finding in this research was related to modes at interval from $1436 \mathrm{~cm}^{-1}$ which correspond to the stretching vibration of $\mathrm{O}-\mathrm{C}-\mathrm{O}$ bonds in the carbonate group $\left(\mathrm{CO}_{3}{ }^{2-}\right)(17,25)$. Mode at frequency $1436 \mathrm{~cm}^{-1}$ is typical for MK-A1-G1 and for IC-A1-G1 (Figure 5). The mode at $881 \mathrm{~cm}^{-1}$ is associated with sodium bicarbonate deformation band (18). Obviously, the presence of the LSG in the mixture contributes to the formation of carbonate species in AAM. The identification of carbonate phases in a number of studied samples, especially in all samples containing LSG, is particularly relevant 
to the interpretation of the results. Such strongly exhibited bands at modes $1436 \mathrm{~cm}^{-1}$ and $881 \mathrm{~cm}^{-1}$ were recognized only in the specimens containing higher amount of LSG (Figure 5). The sodium carbonate or sodium bicarbonate was not found in XRD patterns which could be explained by non-crystallized or semi-crystallized form of carbonates concentrated within pores in the form of pore solution or by dissolving and leaching of carbonate species.

FTIR analysis was performed for all specimens after 20 days of immersion in deionized water (MK-A1-G1-W and IC-A1-G1-W) with the purpose to determinate changes regarding modes at $881 \mathrm{~cm}^{-1}$, $1436 \mathrm{~cm}^{-1}$ which correspond to the stretching vibration of $\mathrm{O}-\mathrm{C}-\mathrm{O}$ bonds in the carbonate group $\left(\mathrm{CO}_{3}{ }^{2-}\right.$ ). The intensity of modes corresponding to $\mathrm{O}-\mathrm{C}-\mathrm{O}$ bonds decreased or disappeared due to leaching of alkali ions and dissolving of carbonates or bicarbonates in the water for the all types of AAM containing LSG as raw material (Figure 5, curves IC-A1-G1-W and MK-A1-G1-W). It was associated with solubility of carbonates and bicarbonates in water media. The interpretation of infrared spectra (FTIR) for all the samples studied is summarized in Table 3.

\subsection{Leaching of $\mathrm{OH}-$ ions}

There are four main parameters characterizing the leaching rate of AAM: porosity of AAM (i), amount of ASRW (ii) and LSG (iii) in the composition as well as to the type of clay used (iv). The typical microstructure of AAM is given in Figure 6. The highest amount of hydroxide ions leached after 20 days (0.0371 mol/1/g $\mathrm{g}_{\mathrm{AAM}}$ ) was for IC-A0.1-G1 with open porosity $16 \%$ and total porosity $78 \%$ (Table 4 and Table 5). The increase of ASRW (IC-A1-G1) reduced leaching rate to $0.0268 \mathrm{~mol} / 1 / \mathrm{g}_{\mathrm{AAM}}$ while porosity of AAM increased (24\% open porosity and $87 \%$ total porosity) (Figure 7a). Similar tendency was observed for AAM based on IC without LSG - the leaching rate for IC-A0.1-G0 (open porosity 23\%, total porosity $69 \%$ ) was $0.0172 \mathrm{~mol} / 1 / \mathrm{g}_{\mathrm{AAM}}$ and it decreased to $0.0123 \mathrm{~mol} / 1 / \mathrm{g}_{\mathrm{AAM}}$ for IC-A1-G0 (open porosity $26 \%$ and total porosity $84 \%$ ). MK-A1-G0 provided similar results with regard to porosity and leaching. The leaching of $\mathrm{OH}$ - ions was slightly higher for samples with higher open porosity $(29 \%)-0.0077$ $\mathrm{mol} / 1 / \mathrm{g}_{\mathrm{AAM}}$ for MK-A1-G0 and $0.0052 \mathrm{~mol} / \mathrm{l} / \mathrm{g}_{\mathrm{AAM}}$ for MK-A0.1-G0 (26\%). The material porosity did

TABLE 3. Interpretation of bands from FTIR spectra of AAM

\begin{tabular}{ll}
\hline Band number and wavelength & Bands interpretation \\
\hline $446 \mathrm{~cm}^{-1}$ & Bending vibration of Si-O-Si or Al-O-Si bonds. \\
$540 \mathrm{~cm}^{-1}$ & $\mathrm{Si}-\mathrm{O}-\mathrm{Al}$ bonds, where $\mathrm{Al}$ is present in octahedral coordination. \\
457 and $688 \mathrm{~cm}^{-1}$ & The symmetrical stretching vibration of Si-O-Si or Al-O-Si bonds. \\
512 and $620 \mathrm{~cm}^{-1}$ & $\mathrm{O}-\mathrm{Si}-\mathrm{O}$ (zeolite species) bond. \\
Doublet at 777 and $795 \mathrm{~cm}^{-1}$ & Quartz. \\
$881 \mathrm{~cm}^{-1}$ & Sodium bicarbonate deformation band. \\
$1014,1016,1020 \mathrm{~cm}^{-1}$ & Various types of bonds including Si-O, Si-O-Si, Si-O-Al, and probably Si-O-Al-(Na). \\
Shoulder at $1100-1200 \mathrm{~cm}^{-1}$ & Si-O stretching vibration (calcined kaolin-metakaolin) . \\
$1436 \mathrm{~cm}^{-1}$ & Sodium carbonate. \\
$1620 \mathrm{~cm}^{-1}$ & Stretching and deformation vibrations of OH and H-O-H groups from water. \\
\hline
\end{tabular}

(a)

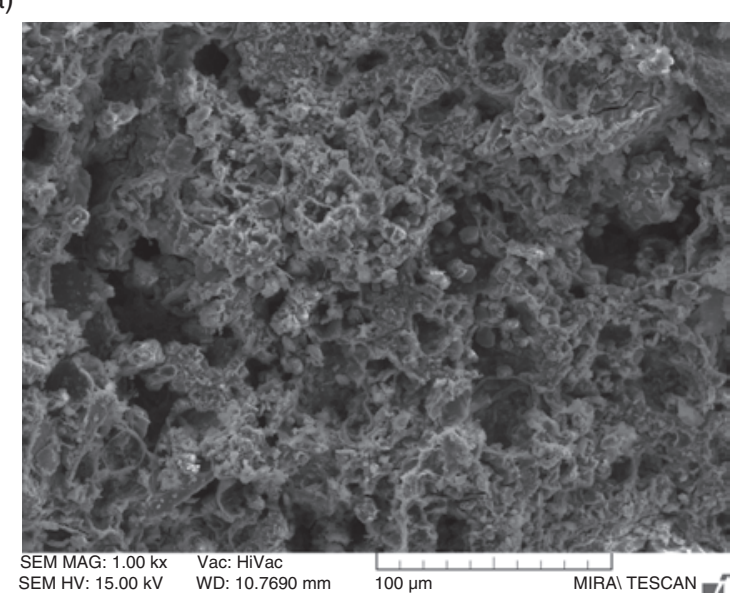

(b)

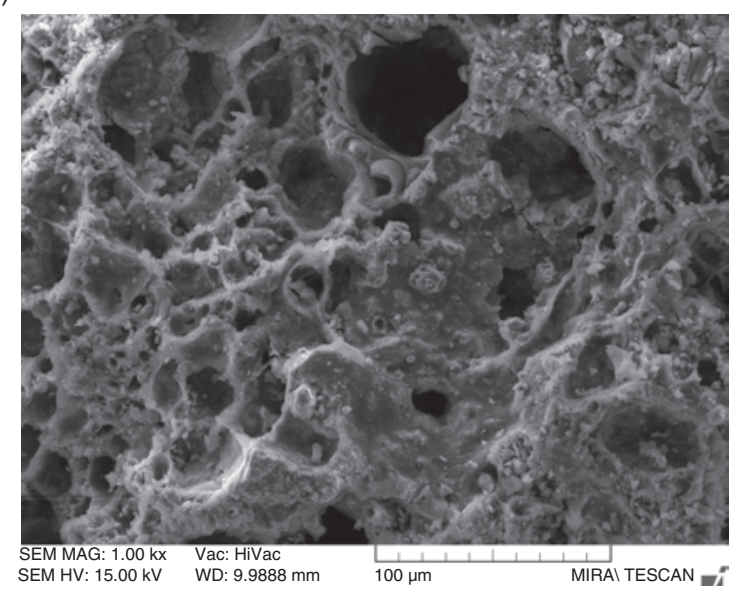

FIGURE 6. The morphological changes of MK-A1-G1: before (a) and after (b) leaching test. 
not influence the leaching rate for AAM based on MK significantly. Different results were obtained for AAM samples based on MK with LSG (Figure 7b). The total porosity of AAM decreased from 84 to $79 \%$ by reduction of ASRW in mixture composition. The open porosity of MK-A1-G1 increased from 16 to $21 \%$ and the leaching of $\mathrm{OH}^{-}$ions was $0.0110 \mathrm{~mol} / \mathrm{l} / \mathrm{g}_{\mathrm{AAM}}$. Leaching rate for MK-A0.1-G1 was slightly lower $-0.0090 \mathrm{~mol} / 1 / \mathrm{g}_{\mathrm{AAM}}$.

The equipollent relationship between leaching rate and porosity was not found, thus it can be concluded that the leaching rate depends on the composition. It seems that ASRW influences mixture composition and the leaching rate of hydroxide ions; lower amount of ASRW increased leaching rate of alkali ions for AAM made of IC. Most likely it can be explained by geopolymerization process of raw materials where ASRW provides increased amount

TABLE 4. Physical properties of alkali activated materials (AAM)

\begin{tabular}{lccc}
\hline Composition & $\begin{array}{c}\text { Density } \\
\left(\mathbf{g}_{\mathbf{c m}} \text { ) }\right.\end{array}$ & $\begin{array}{c}\text { Open porosity } \\
\text { (vol.\%) }\end{array}$ & $\begin{array}{c}\text { Total porosity } \\
\text { (vol.\%) }\end{array}$ \\
\hline IC-A1-G0 & 319 & 26 & 84 \\
IC-A0.5-G0 & 317 & 26 & 77 \\
IC-A0.1-G0 & 516 & 23 & 69 \\
IC-A1-G1 & 382 & 24 & 87 \\
IC-A0.5-G1 & 498 & 18 & 87 \\
IC-A0.1-G1 & 683 & 16 & 78 \\
MK-A1-G0 & 357 & 29 & 84 \\
MK-A0.5-G0 & 385 & 25 & 83 \\
MK-A0.1-G0 & 358 & 26 & 83 \\
MK-A1-G1 & 355 & 16 & 84 \\
MK-A0.5-G1 & 393 & 19 & 81 \\
MK-A0.1-G1 & 437 & 21 & 79 \\
\hline
\end{tabular}

of $\mathrm{Al}_{2} \mathrm{O}_{3}$. The fact that leaching rate for AAM based on MK was not strongly influenced by the amount of ASRW in the composition could be explained by several factors: the amount of ASRW added to mixture composition did not have significant impact on material porosity; MK has higher amount of $\mathrm{Al}_{2} \mathrm{O}_{3}$ compared to IC; and aluminium content of the AAM does not play such an important role in removing alkali ions from the pore solution; total amount of $\mathrm{Ca}$ in MK based AAM system is higher compared to AAM made of IC.

The general tendency for all samples analyzed in this research is that leaching rate decreased for AAM made of both clays without LSG compared with samples with LSG.

The leaching rate could be attributed to the $\mathrm{SiO}_{2} /$ $\mathrm{Al}_{2} \mathrm{O}_{3}$ and $\mathrm{Na}_{2} \mathrm{O} / \mathrm{Al}_{2} \mathrm{O}_{3}$ mass ratio of AAM (Table 5 and Figure 8). MK has higher $\mathrm{Al}_{2} \mathrm{O}_{3}$ content compared with IC (Table 1) therefore the AAM made with $\mathrm{MK}$ has lower $\mathrm{SiO}_{2} / \mathrm{Al}_{2} \mathrm{O}_{3}$ ratio compared with AAM based on IC and lower amount of total leached $\mathrm{OH}^{-}$ions. By reducing ASRW in the composition, both $\mathrm{SiO}_{2} / \mathrm{Al}_{2} \mathrm{O}_{3}$ and $\mathrm{Na}_{2} \mathrm{O} / \mathrm{Al}_{2} \mathrm{O}_{3}$ ratio and leaching rate increased significantly for AAM samples made with IC, while for AAM based on MK the effect of ASRW on leaching rate was reversed and leaching rate decreased. By using LSG in the composition, the $\mathrm{SiO}_{2} / \mathrm{Al}_{2} \mathrm{O}_{3}$ ratio increased; therefore the leached amount of $\mathrm{OH}^{-}$ions was higher for all AAM made with LSG. The relevance of main oxide ratios to the leaching of $\mathrm{OH}^{-}$ions was calculated and leaching model was obtained (Figure 8). The leaching rate was analyzed on $1^{\text {st }}$ and $20^{\text {th }}$ day after leaching test. More precise correlation was observed at early age (on $1^{\text {st }}$ day) and scattering increased on $20^{\text {th }}$ day. The correlation between main oxide ratios and leaching could be regarded as acceptable while the results at later age can be affected by the physical properties of AAM.

TABLE 5. $\mathrm{SiO}_{2} / \mathrm{Al}_{2} \mathrm{O}_{3}$ mass ratio and results of leaching test

\begin{tabular}{|c|c|c|c|c|c|}
\hline \multirow[b]{2}{*}{ Mixture composition } & \multirow[b]{2}{*}{$\mathrm{SiO}_{2} / \mathrm{Al}_{2} \mathrm{O}_{3}$ mass ratio } & \multirow{2}{*}{$\begin{array}{c}\text { Total amount of leached } \mathrm{OH}^{-} \text {after } \\
\left.20 \text { days mol/l/g } \mathrm{g}_{\text {AAM }}\right)\end{array}$} & \multicolumn{3}{|c|}{ pH of leachate after } \\
\hline & & & $1^{\text {st }}$ day & $5^{\text {th }}$ day & $20^{\text {th }}$ day \\
\hline IC-A1-G0 & 1.40 & 0.0123 & 11.6 & 10.2 & 8.1 \\
\hline IC-A0.5-G0 & 2.00 & 0.0135 & 11.6 & 9.9 & 7.3 \\
\hline IC-A0.1-G0 & 3.90 & 0.0172 & 11.8 & 9.2 & 6.2 \\
\hline IC-A1-G1 & 2.50 & 0.0268 & 11.8 & 10.4 & 8.6 \\
\hline IC-A0.5-G1 & 3.80 & 0.0323 & 11.9 & 10.2 & 8.0 \\
\hline IC-A0.1-G1 & 7.60 & 0.0371 & 11.8 & 9.8 & 7.8 \\
\hline MK-A1-G0 & 0.90 & 0.0077 & 11.1 & 9.8 & 7.8 \\
\hline MK-A0.5-G0 & 1.20 & 0.0061 & 10.6 & 9.4 & 7.6 \\
\hline MK-A0.1-G0 & 1.60 & 0.0052 & 10.8 & 9.4 & 7.4 \\
\hline MK-A1-G1 & 1.80 & 0.0110 & 11.2 & 10.1 & 8.4 \\
\hline MK-A0.5-G1 & 2.40 & 0.0095 & 11.1 & 10.0 & 8.4 \\
\hline MK-A0.1-G1 & 3.40 & 0.0090 & 11.2 & 9.9 & 8.5 \\
\hline
\end{tabular}


(a)

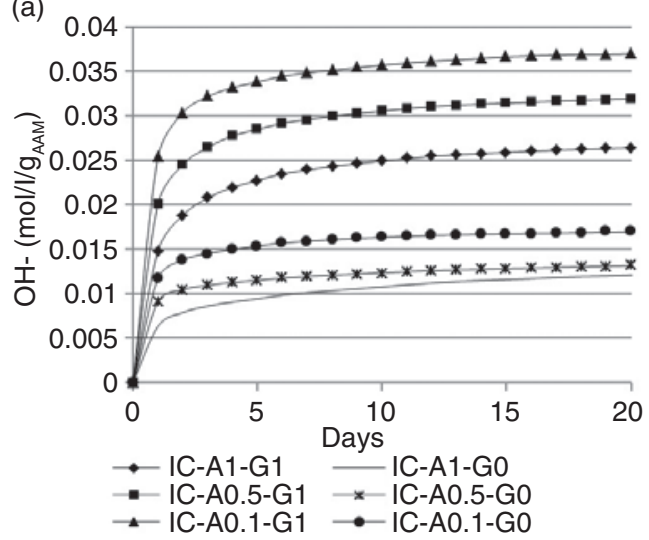

(b)

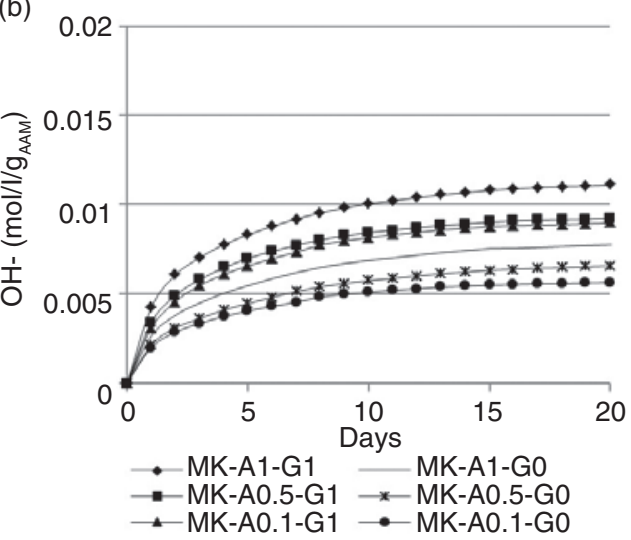

Figure 7. Amount of $\mathrm{OH}^{-}$leached from 28 days old AAM: a) made from calcined illite clay (IC) and b) made from metakaolin (MK); in the deionized water after 20 days of immersion

(a)

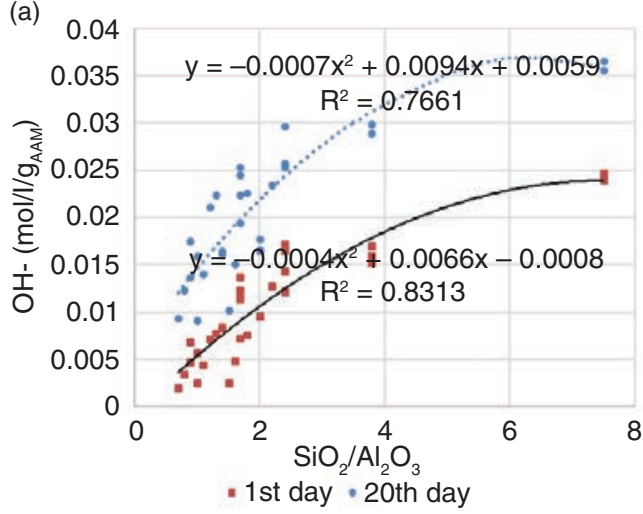

(b)

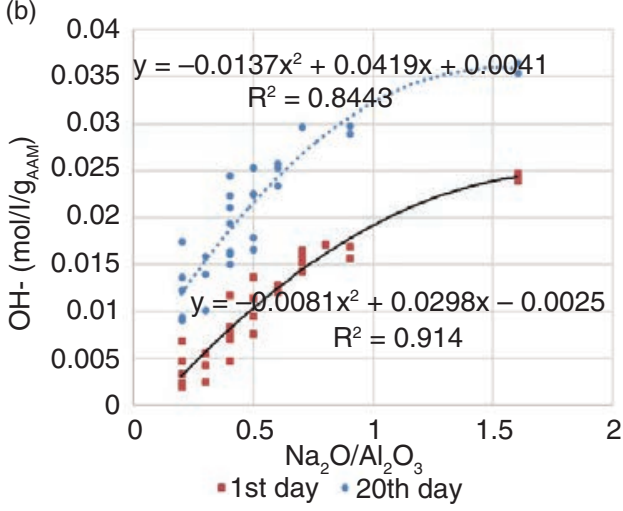

FigurE 8. The correlation between main oxide ratio of AAM and leaching on $1^{\text {st }}$ and $20^{\text {th }}$ day: leaching rate in function of the $\mathrm{SiO}_{2} / \mathrm{Al}_{2} \mathrm{O}_{3}$ (a) and $\mathrm{Na}_{2} \mathrm{O} / \mathrm{Al}_{2} \mathrm{O}_{3}$ (b) ratios

\section{CONCLUSIONS}

In general, the amount of ASRW and LSG, and the type of clay used in the composition of AAM affect leaching rate of alkali ions. ASRW is also responsible for the creation of porous structure, which was characterized by open and total porosity. LSG in its turn can affect reaction between the activator and calcined clay minerals (approved by FTIR) and enhances the appearance of sodium carbonates or bicarbonates.

The AAM made of IC can leach on average 3 times more alkali ions than AAM made with MK mainly due to a higher $\mathrm{SiO}_{2} / \mathrm{Al}_{2} \mathrm{O}_{3}$ ratio which may influence pore solution transfer to the leachate. AAM made from IC leached 50 to $70 \%$ of the totally leached amount of $\mathrm{OH}^{-}$ions during the first day; the reduction of ASRW in mixture composition of AAM led to higher leaching rate. Higher amount of LSG in its turn could increase the total leaching of alkalis significantly. The AAM made with MK leached significantly smaller amount of $\mathrm{OH}^{-}$ions during the first day compared to AAM made of IC; the amount of ASRW in composition had smaller effect on the leaching rate, but the effect of LSG was equivalent as for the AAM based on IC.

The obtained alkali activated materials are suitable for biotechnological processes where acidic substances are used, and where it is necessary to increase $\mathrm{pH}$ rapidly at the beginning of the process (first 5 days) and then keep it constant in the range of $\mathrm{pH}$ 6-7 for next 20 days. In the cases, where the acidity of substances used in biotechnology processes is lower, AAM made from MK is more suitable because only 30 to $40 \%$ was leached during the first day. The leaching of $\mathrm{OH}^{-}$ions from the AAM made with MK was more even compared with AAM based on IC. The obtained materials have various buffering capacity rates and long term alkali diffusion to restrict $\mathrm{pH}$ decrease in biogas production process.

\section{ACKNOWLEDGEMENTS}

This work has been supported by ESF project "Involvement of Human Resources for Development of Integrated Renewable Energy 
Resources Energy Production System", No. Nr.2013/0014/1DP/1.1.1.2.0/13/APIA/VIAA/026.

\section{REFERENCES}

1. Montalvo, S.; Guerrero, L.; Borja, R. (2012) Application of natural zeolites in anaerobic digestion processes: A review. Appl Clay Sci. 58:125-133. https://doi.org/10.1016/j. clay.2012.01.013

2. Lloyd. R.R.; Provis, J.L.; Van Deventer J.S.J. (2010) Pore solution composition and alkali diffusion in inorganic polymer cement. Cem Concr Res. 40(9):1386-1392. https:// doi.org/10.1016/j.cemconres.2010.04.008

3. Aly, Z.; Vance E.R.; Perera D.S. (2008) Aqueous leachability of metakaolin-based geopolymers with molar ratios of Si/Al=1.5-4. J Nucl Mater. 378(2):172-179. https://doi. org/10.1016/j.jnucmat.2008.06.015

4. Xie, T.; Ozbakkaloglu, T. (2015) Behavior of low-calcium fly and bottom ash-based geopolymer concrete cured at ambient temperature. Ceram Int. 41(4):5945-5958. https:// doi.org/10.1016/j.ceramint.2015.01.031

5. Duxson, P.; Lukey G.C.; Separovic, F.; Van Deventer, J.S.J. (2005) Effect of alkali cations on aluminum incorporation in geopolymeric gels. Ind Eng Chem Res. 44(4):832-839. https://doi.org/10.1021/ie0494216

6. Hong, S.Y.; Glasser, F.P. (2002) Alkali sorption by $\mathrm{C}-\mathrm{S}-\mathrm{H}$ and C-A-S-H gels: Part II. Role of alumina Cem Concr Res. 32(7):1101-1111. https://doi.org/10.1016/ S0008-8846(02)00753-6

7. Yan, B.; Duan, P.; Ren, D. (2017) Mechanical strength, surface abrasion resistance and microstructure of fly ash-metakaolin-sepiolite geopolymer composites. Ceram Int. 43(1):1052-1060. https://doi.org/10.1016/j. ceramint.2016.10.039

8. Lloyd, R.R.; Provis, J.L.; Van Deventer, J.S.J. (2009) Microscopy and microanalysis of inorganic polymer cements. 1: Remnant fly ash particles. J Mater Sci. 44(2):608-619. https://doi.org/10.1007/s10853-008-3077-0

9. Hlaváček, P.; Šmilauer, V.; Skvára, F.; Kopecký, L.; Sulc, R. (2015) Inorganic foams made from alkali-activated fly ash: Mechanical, chemical and physical properties. $J$ Eur Ceram Soc. 35(2):703-709. https://doi.org/10.1016/j. jeurceramsoc.2014.08.024

10. Komnitsas, K.; Zaharaki, D.; Bartzas, G. (2013) Effect of sulphate and nitrate anions on heavy metal immobilisation in ferronickel slag geopolymers. Appl Clay Sci. 73:103-109. https://doi.org/10.1016/j.clay.2012.09.018

11. Zheng, L.; Wang, C.; Wang, W.; Shi, Y.; Gao, X. (2011) Immobilization of MSWI fly ash through geopolymerization: effects of water-wash. Waste Manag. 31(2):311-317. https://doi.org/10.1016/j.wasman.2010.05.015

12. Tsakiridis, P.E. (2012) Aluminium salt slag characterization and utilization - A review. J Hazard Mater. 217-218:1-10. https://doi.org/10.1016/j.jhazmat.2012.03.052
13. Bai, C.; Franchin, G.; Elsayed, H.; Conte, A.; Colombo, P. (2016) High strength metakaolin-based geopolymer foams with variable macroporous structure. $J$ Eur Ceram Soc. 36(16):4243-4249. https://doi.org/10.1016/j. jeurceramsoc.2016.06.045

14. Ilic, B; Mitrovic, A ; Milicic, L (2010) Thermal treatment of kaolin clay to obtain metakaolin. Hem Ind. 64(4):351356. https://doi.org/10.2298/HEMIND100322014I

15. Liew, Y.M ; Kamarudin, H. Mustafa Al Bakri, A.M. (2012) Processing and characterization of calcined kaolin cement powder. Constr Build Mater. 30:794-802. https:// doi.org/10.1016/j.conbuildmat.2011.12.079

16. Bohor, B.F. High-Temperature Phase Development in Illitic Clays. http://www.clays.org/journal/archive/volume $\% 20$ 12/12-1-233.pdf. Accessed March 28, 2017

17. Baščarević, Z; Komljenović, M.; Miladinović, Z. (2013) Effects of the concentrated $\mathrm{NH}_{4} \mathrm{NO}_{3}$ solution on mechanical properties and structure of the fly ash based geopolymers. Constr Build Mater. 41(3):570-579. https://doi. org/10.1016/j.conbuildmat.2012.12.067

18. Bernal, S.A.; Gutierrez, R.M.M. de; Provis, J.L.; Rose, V. (2010) Effect of Silicate Modulus and Metakaolin incorporation on the carbonation of alkali silicate-activated slags. Cem Concr Res. 40(6):898-907. https://doi.org/10.1016/j. cemconres.2010.02.003

19. Bajare, D; Bumanis, G; Korjakins, A. (2014) New Porous Material Made from Industrial and Municipal Waste for Building Application. Mater Sci. 20(3):333-338. https:// doi.org/10.5755/j01.ms.20.3.4330

20. Bajare, D. Bumanis, G. (2014) Alkali diffusion in porous alkali activated materials. In: NTCC 2014: International Conference on Non-Traditional Cement and Concrete. 1-9.

21. Hajimohammadi, A. Provis JL. van Deventer J.J. (2011) The effect of silica availability on the mechanism of geopolymerisation. Cem Concr Res. 41(3):210-216. https:// doi.org/10.1016/j.cemconres.2011.02.001

22. Zhang, Z.; Wang, H.; Provis, J.L.; Bullen, F.; Reid, A.; Zhu, Y. (2012) Quantitative kinetic and structural analysis of geopolymers. Part 1 . The activation of metakaolin with sodium hydroxide. Therm Acta 539:23-33. https://doi. org/10.1016/j.tca.2012.03.021

23. Criado, M.; Palomo, A.; Fernández-Jiménez, A. (2005) Alkali activation of fly ashes. Part 1: Effect of curing conditions on the carbonation of the reaction products. Fuel. 84(16):2048-2054. https://doi.org/10.1016/j. fuel.2005.03.030

24. Burciaga-Díaz, O.; Escalante-García, J.I (2012) Strength and Durability in Acid Media of Alkali Silicate-Activated Metakaolin Geopolymers. Scherer G, ed. J Am Ceram Soc. 95(7):2307-2313. https://doi. org/10.1111/j.1551-2916.2012.05249.x

25. Bernal, S.A.; Mejía de Gutiérrez, R.; Pedraza, A.L.; Provis, J.L.; Rodriguez, E.D.; Delvasto, S. (2011) Effect of binder content on the performance of alkali-activated slag concretes. Cem Concr Res. 41(1):1-8. https://doi.org/10.1016/j. cemconres.2010.08.017 